\title{
DIGITAL SPECTRAL ANALYSIS ON THE PLANE OF COMPLEX FREQUENCIES OF TRANSIENTS OF THE HEART RHYTHM AT SCHOOLCHILDREN AT PERFORMING A PROOF TEST
}

\author{
A.N. Ragozin', ragozinan@susu.ru, \\ V.F.Telezhkin ${ }^{1}$, telezhkinvf@susu.ru, \\ A.M. Usynin' ${ }^{2}$ dgb1@uzag74.ru, \\ L.Ya. Dotsoev ${ }^{3}$, dozoevl@mail.ru, \\ A.D. Pletenkova ${ }^{1}$, nastya.pletenkova@mail.ru, \\ B.B. Saidov ${ }^{1,4}$, matem.1994@mail.ru \\ ${ }^{1}$ South Ural State University, Chelyabinsk, Russian Federation, \\ ${ }^{2}$ South Ural State Medical University, Chelyabinsk, Russian Federation, \\ ${ }^{3}$ South Ural State Humanitarian Pedagogical University, Chelyabinsk, Russian Federation, \\ ${ }^{4}$ Tajik Technical University named after academician M.S. Osimi, Dushanbe, Republic of Tajikistan
}

\begin{abstract}
Introduction. The method of processing experimental data obtained in the form of a timevarying non-stationary signal is described. In the experimental study of transients associated with changes in the heart rate of schoolchildren during a proof-reading test, it became necessary to develop a new effective method for processing the results of dynamic measurements. Purpose of the study. Consider the main points of this methodology, which is based on the Prony method, and the possibility of its use in the field of studies of changes in heart rate variability (HRV) in response to various functional test influences. Materials and methods. Traditional approaches related to the calculation of power spectral density (PSD) and based on classical spectral methods are currently very widespread. The model of constant rhythm is not applicable for non-stationary dependencies of HRV. For spectral analysis of time dependences of HRV reflecting transient processes (nonstationary processes) it is proposed to apply spectral analysis on the plane of complex frequencies (PCF). PCF is a generalization of the usual spectrum. The calculation of the PCF is based on the Prony procedure, based on parametric modeling. Results. PCF reflects the frequency structure of oscillations of unsteady physiological signals, therefore, can be used to classify them. It is shown that the use of spectral analysis on the plane of complex frequencies for transient processes of the heart rhythm makes it possible (according to the parameters of the PCF) to calculate, for diagnostic purposes, the numerical values of the parameters characterizing the reactions of various regulatory mechanisms of the heart rhythm in response to various functional test influences. Conclusion. The best results, as compared with the methods of classical spectral analysis, for the analysis of transients in the form of a HRV signal were given by approaches based on the use of spectral analysis on the plane of complex frequencies.

Keywords: heart rate variability, Prony's method, spectrum on the plane of complex frequencies, physiological signals, heart rhythm, parametric model.
\end{abstract}

\section{Introduction}

Traditional methods for analyzing heart rate variability (HRV) using the spectrum on the plane of complex frequencies (SCF), which can be represented as physically realized signals and time series generated by complex (multimodal) dynamic systems, are mainly based on various spectral correlation methods. Moreover, due to the statistical approach to the analysis of signals, the dynamic nature of the processes that generate them, as a rule, goes by the wayside. Only a dynamic approach to the analysis of changes in heart rate in schoolchildren during a proof-reading test allows to consider signal analysis as a process of identifying dynamic systems based on the results of an analysis of experimental data. In contrast to Fourier spectral analysis, spectral analysis on the plane of complex frequencies allows to: 1) to perform without spectral effects spectral estimation of time series segments in time windows of limited duration; 2) to use a non-stationary time series model; 3) to determine the own frequency spectrum and the spectrum of modal damping of the system modes that are manifested in this segment of the time series. The Prony's method lacks a number of limitations inherent in the fast Fourier transform (FFT). 


\section{Краткие сообщения}

\section{Problem statement}

The work is devoted to the experimental study of transients of the heart rhythm in three types of state when the heart rate changes in schoolchildren during a proof-reading test. As a research tool, the method of spectral analysis on the plane of complex frequencies is used. The parameters for constructing the spectrum of complex frequencies are: $\mathrm{f}, \alpha, \mathrm{p}-$ harmonic frequency $[\mathrm{Hz}]$, coefficient of harmonic amplitude change according to exponential law $\left[\mathrm{s}^{-1}\right]$ and harmonic power [unit of measurement $\left.^{2}\right]$. The method expands the possibilities of studying the physiological regulation of transients in the body of children and teenagers during the educational process.

Studying the student's functional capabilities when performing stress tests is of great practical importance for determining the level of functional tension of the child's regulatory systems, which is determined by the degree of physiological maturity of the body and environmental conditions. Change in heart rate - a universal operational response of the whole organism to any environmental impact. One of the important links of this mechanism provides a balance between the sympathetic and parasympathetic departments of the autonomic nervous system $[1,2]$. Heart rate variability indicators reflect the state of the autonomic nervous system, the degree of tension of regulatory mechanisms, therefore, it is important to study them in children of different ages in conditions of adaptation to school loads, which plays an important role in the prevention of diseases $[3,4]$. Transitional states of the physiological system proceed with a pronounced activation of some regulation rhythms and suppression of others, which is manifested by a change in the nature of the structural-temporal organization of vibrational activity [5]. Thus, it is required to show that a deep assessment of the state of the autonomic nervous system is possible through the use of spectral analysis of HRV [6-14].

\section{Solution}

It should be noted that when using spectral analysis, the action of the regulation mechanisms during the registration of the heart rhythm should remain constant (stationary observation conditions). The temporary recording of HRV should be the implementation of a stationary random process, that is, the process on average is uniform in time (the variance and mean are constant over time). The transient processes of HRV caused by the influence of a functional test are non-stationary processes and therefore are excluded during the spectral analysis. To analyze transient processes of heart rhythm, the technology of spectral analysis on the plane of complex frequencies is used [15-23].

The calculation of the SCF implies the representation of the studied HRV dependence as the sum of a certain number of sinusoids (harmonics), characterized by a phase, frequency and amplitude, which changes in time (constant $\alpha=0)$, increasing $(\alpha>0)$, or decaying $(\alpha<0)$, by exponential law $\left(\mathrm{e}^{\alpha t}\right)$. The basis for the algorithm for calculating the SCF is the Prony procedure. The investigated time process of HRV is represented as a set of rhythms with different frequencies, initial phases, but with varying intensities by exponential law. The set of harmonics into which the process under study decomposes must correspond to its nature. The harmonics varying in amplitude reflect the adjustment process and the change in the frequency composition of the process under study. The adjustment process can be observed separately by the generally accepted frequency ranges [16].

The parameters for constructing the SCF HRV are: $\mathrm{f}$ - harmonic frequency $[\mathrm{Hz}], \alpha$ - coefficient of variation of the harmonic amplitude according to the exponential law $\left[\mathrm{s}^{-1}\right], \mathrm{P}-$ harmonic power $\left[\mathrm{ms}^{2}\right]$. SCF is displayed in the form of lines with height P, placed on the plane of the complex frequency $(f, \alpha)$. If the time dependence of the HRV is strictly stationary, then the harmonics into which the studied dependence of the HRV is decomposed will have constant in time amplitudes $(\alpha=0)$ (intensity) and the SCF takes the form of a usual spectrum [16].

The information content of indicators considered on the basis of the SCF is shown in [16]. The transition process of insertion is based on the activation of the sympathetic and suppression of the parasympathetic departments of the autonomic nervous system, which leads to an increase in the number of heart contractions (HC) and a decrease in heart rate variability (HR). This means that changes in the vibrational activity of the heart rate observed during the transition process of working in should occur in at least three frequency ranges: low-frequency trend (deviation), oscillations at low frequencies (activation and suppression) and at frequencies of respiratory arrhythmia (suppression). In solving the problem of the present work, 71 healthy third-grade students were examined. Heart rate variability was recorded: one minute at rest, running in and exertion while performing a proof test. To study the quantitative and 
qualitative characteristics of the transition process, spectral analysis was applied on the plane of complex frequencies [15-23]. The energy (E) of increasing and damping oscillations reflects the overall energy balance of the transition process, and the nature of the transition process is quantified by the instability and periodicity indices [15-23]. The instability of the vibrational process refers to the intensity in time of the easing or increasing fluctuations. The instability index (ANN) is calculated as the ratio of the magnitude of the observation period of the transient to the time interval of the change in vibrational energy (attenuation or amplification of the oscillations) e times (e is the Euler number equal to 2.72 ...). The periodicity index (PI) of an unsteady process shows the number of periods that fit into the time interval of a change in vibrational energy by e times.

The greater the module of the instability index, the more pronounced the aperiodic nature of the transition process. Conversely, the larger the module of the periodicity index, the more the trend of the transition process appears to be oscillations that are stable in amplitude. The sign in front of the indices of instability and periodicity indicates the decaying or increasing character of the dynamics of the transitional oscillatory process.

Thus, these indicators obtained using spectral analysis on the plane of complex frequencies contain important information about the structure of the transient oscillatory process and can serve as indicators of the quality of the regulatory system.

The boundaries of the frequency ranges in the spectrum of complex frequencies, from 0 to $0.05 \mathrm{~Hz}$ (VLF), 0.05 to $0.15 \mathrm{~Hz}$ (LF), 0.15 to $0.6 \mathrm{~Hz}(\mathrm{HF})$, reflect generally accepted ideas about the mechanisms of manifestation of the sympathetic and parasympathetic parts of the autonomic nervous system. Heart rate transient indicators: $\mathrm{E}_{\mathrm{VLF}}\left(\mathrm{ms}^{2}\right)$ - transient integrated energy in the frequency range from 0 to $0.05 \mathrm{~Hz} ; \mathrm{E}_{\mathrm{LF}}\left(\mathrm{ms}^{2}\right)$ - frequency transient integrated energy from 0.05 to $0.15 \mathrm{~Hz} ; \mathrm{E}_{\mathrm{HF}}\left(\mathrm{ms}^{2}\right)-$ the integral energy of the transition process in the frequency range from 0 to $0.6 \mathrm{~Hz}$; $\mathrm{PI}_{\mathrm{VLF}}-$ periodicity index in the range of frequencies from 0 to $0.05 \mathrm{~Hz}$; $\mathrm{INS}_{\mathrm{VLF}}$ - heart rate instability index in the range of frequencies from 0 to $0.05 \mathrm{~Hz} ; \mathrm{PI}_{\mathrm{LF}}-$ heart rate index in the range of frequencies from 0.05 to $0.15 \mathrm{~Hz}$; INS $\mathrm{S}_{\mathrm{LF}}-$ heart rate instability index in the frequency range from 0.05 to $0.15 \mathrm{~Hz} ; \mathrm{PI}_{\mathrm{HF}}-$ heart rate index in the range of frequencies from 0.15 to $0.6 \mathrm{~Hz} ; \mathrm{INS}_{\mathrm{HF}}$ - heart rate instability index in the frequency range from 0.15 to $0.6 \mathrm{~Hz}$; Depending on the ratio between the values of $\mathrm{E}_{\mathrm{VLF}}, \mathrm{E}_{\mathrm{LF}}$ и $\mathrm{E}_{\mathrm{HF}}$ we distinguished three variants of heart rate dynamics in children. The first option, in which the integrated transient energy prevails at the lowest frequencies, so that the ratio of EVLF to the sum of ELF and EHF is greater than or equal to 0.5 . The basis of the transition process of this option is the oscillation represented by the low-frequency decaying cosine wave. The spectrum on the plane of complex frequencies has a pronounced peak at the corresponding low frequency (Fig. 1).
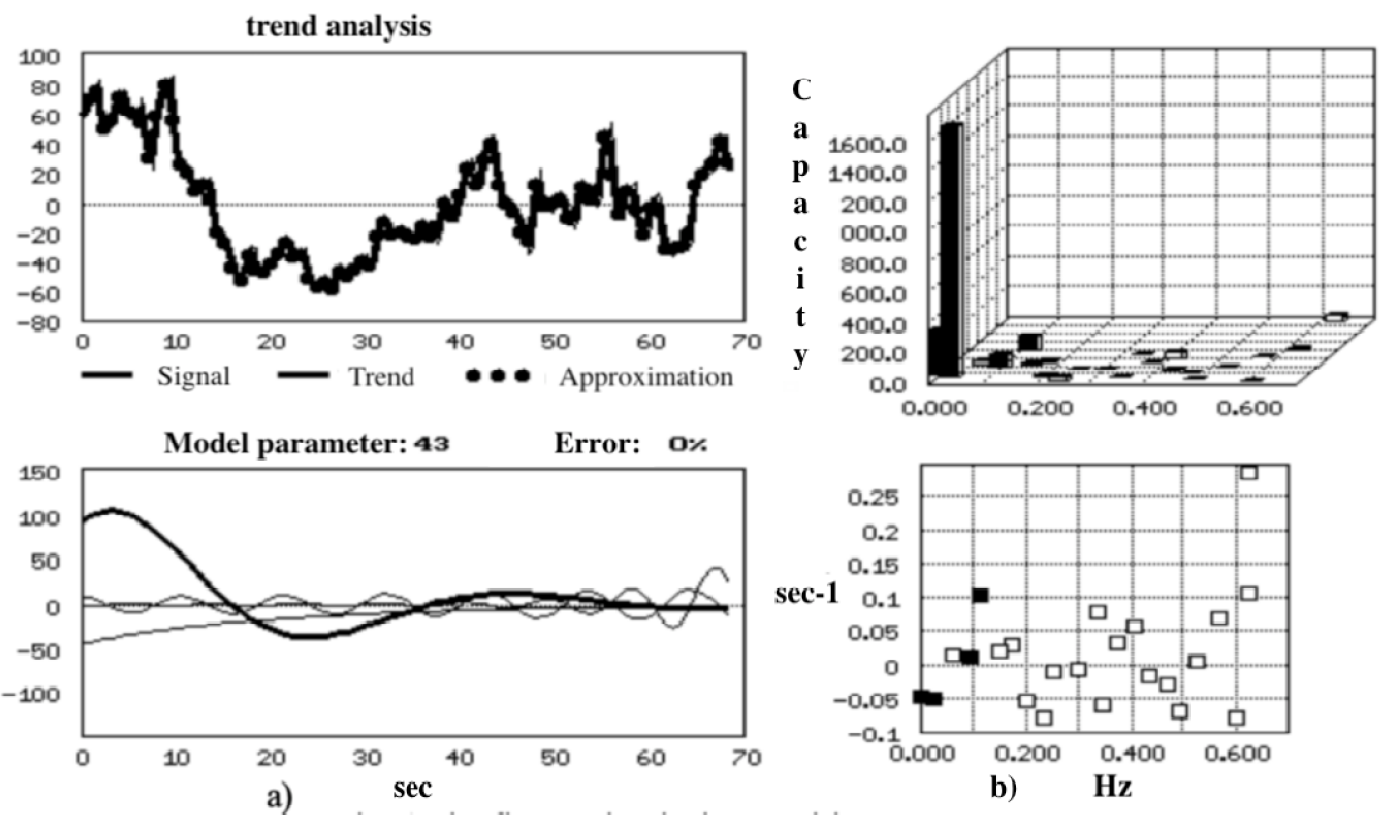

Fig. 1. The first option is the transition process: a) heart rate dynamics, b) the spectrum of heart rate transition on the plane of complex frequencies 


\section{Краткие сообщения}

In the second option, the integrated low-frequency LF energy dominates, where the ratio of ELF to the sum of EHF and EVLF is greater than or equal to 0.5. This transient process appears to be several low-frequency cosine waves, both fading and increasing. Their power and character are reflected in the spectrum on the plane of complex frequencies (Fig. 2).
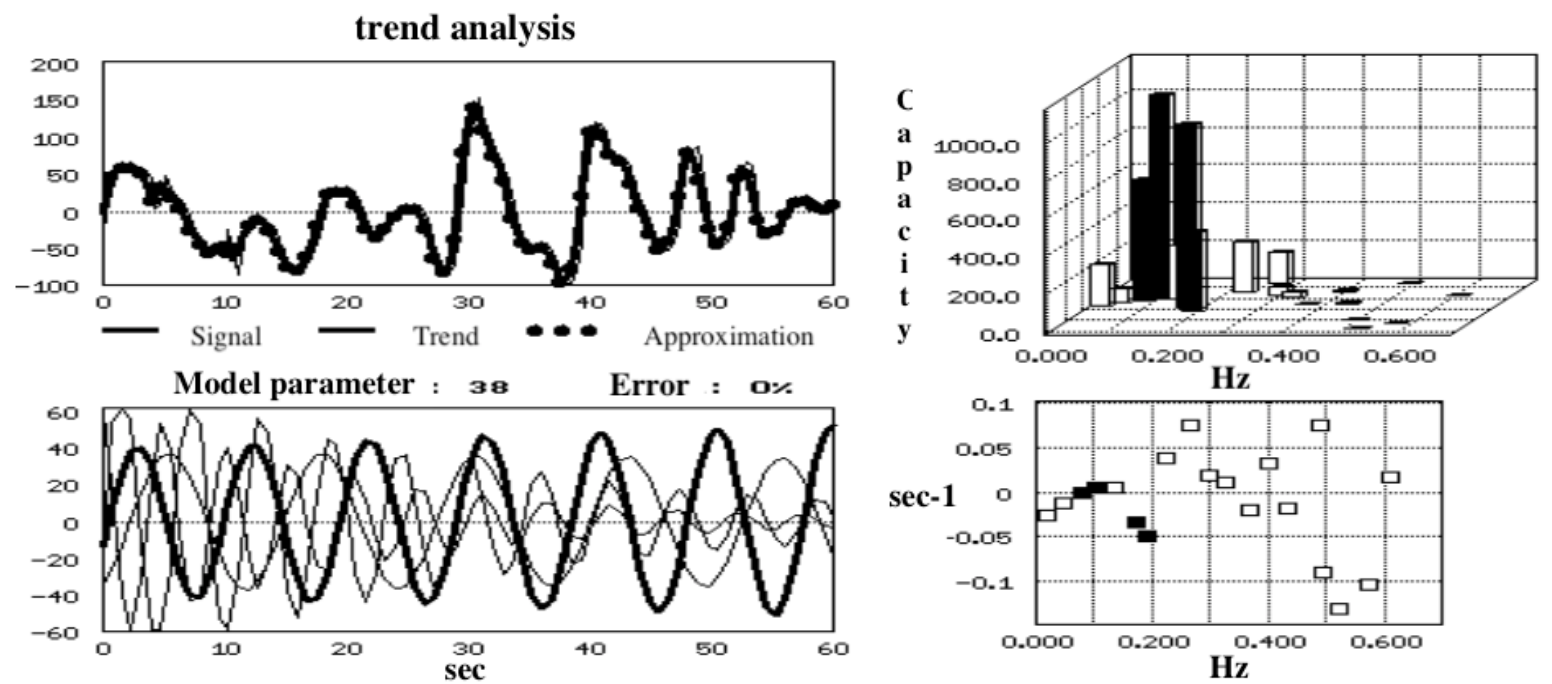

a)

b)

Fig. 2. The second option is the transition process: a) heart rate dynamics,

b) the spectrum of heart rate transition on the plane of complex frequencies

In the third option, the ratio $E_{\mathrm{HF}}$ to the sum $\mathrm{E}_{\mathrm{VLF}}$ и $\mathrm{E}_{\mathrm{LF}}$ is greater or equal to 0.5. This means that most of the transient energy is in the high frequency range HF. As a result of the analysis, this heart rate dynamics is represented in the form of a high-frequency, highly decaying cosine wave, whose power prevails over the low-frequency components of the transition process (Fig. 3).
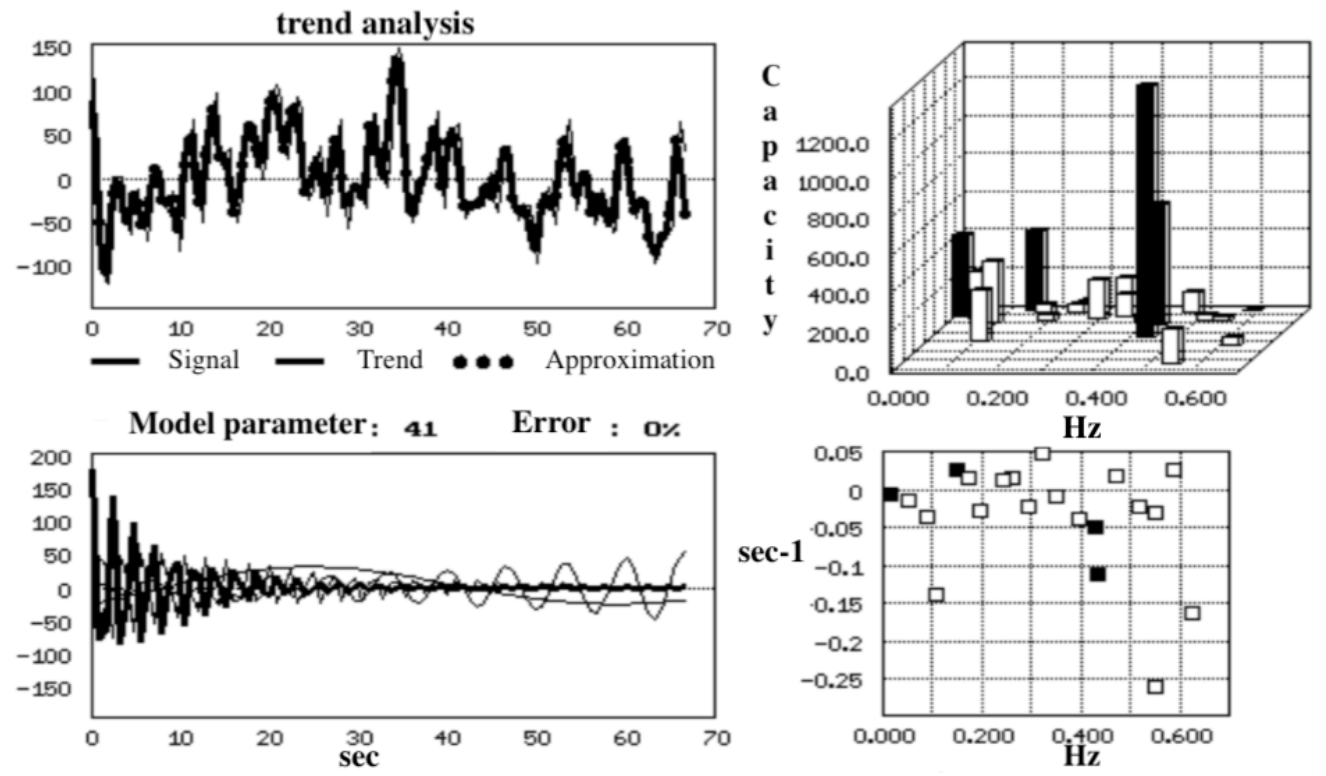

a)

b)

Fig. 3. The third option is the transition process: a) heart rate dynamics, b) spectrum on the plane of complex frequencies

Thus, according to the variants of heart rhythm dynamics, three groups were formed: group 1 was represented by children in whom EVLF - 37 children prevailed, group 2 - 19 children, ELF dominated in them, and group 3 - children in which EHF - dominated by 15 people (Table 1). 
Distribution of children into groups, depending on the severity of the energy transition process $(M \pm S D)$

\begin{tabular}{|c|c|c|c|}
\hline & Group $1 \mathrm{n}=37$ & Group 2 $\mathrm{n}=19$ & Group 3 $\mathrm{n}=15$ \\
\hline $\mathrm{E}_{\mathrm{VLF}}$ & $0.54 \pm 0.13^{*}$ & $0.22 \pm 0.11$ & $0.21 \pm 0.11$ \\
\hline $\mathrm{E}_{\mathrm{LF}}$ & $0.23 \pm 0.11$ & $0.52 \pm 0.11^{*}$ & $0.24 \pm 0.13$ \\
\hline $\mathrm{E}_{\mathrm{HF}}$ & $0.23 \pm 0.12$ & $0.26 \pm 0.08$ & $0.55 \pm 0.11^{*}$ \\
\hline
\end{tabular}

Note $* \mathrm{P}<0,05$

In all groups, during exercise, a significant transition to a new, higher level of functioning of the cardiovascular system was noted. It was manifested by a more frequent and less variable heart rate (Table 2).

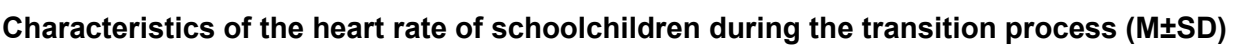

\begin{tabular}{|l|c|c|c|}
\hline & Group 1 & Group 2 & Group 3 \\
\hline $\begin{array}{l}\text { Concentration } \\
\text { of attention (proof test) }\end{array}$ & $91 \pm 84$ & $36 \pm 17^{*}$ & $52 \pm 51^{*} \sim$ \\
\hline $\mathrm{E}_{\mathrm{VLF}}$ & $1479 \pm 1247$ & $659 \pm 991^{*}$ & $631 \pm 473^{*}$ \\
\hline $\mathrm{PI}_{\mathrm{VLF}}$ & $-0.45 \pm 0.93$ & $-0.52 \pm 2.02$ & $-0.53 \pm 1.21$ \\
\hline $\mathrm{INS}_{\mathrm{VLF}}$ & $-7.65 \pm 9.14$ & $-2.21 \pm 5.57^{*}$ & $-5.29 \pm 9.66$ \\
\hline $\mathrm{E}_{\mathrm{LF}}$ & $682 \pm 787$ & $1276 \pm 1166^{*}$ & $625 \pm 556 \sim$ \\
\hline $\mathrm{PI}_{\mathrm{LF}}$ & $0.72 \pm 9.49$ & $1.19 \pm 9.91$ & $-12.76 \pm 40.23$ \\
\hline $\mathrm{INS}_{\mathrm{LF}}$ & $-1.52 \pm 3.8$ & $-2.68 \pm 3.2$ & $-0.36 \pm 3.84 \sim$ \\
\hline $\mathrm{E}_{\mathrm{HF}}$ & $570 \pm 747$ & $635 \pm 633$ & $1676 \pm 1419^{*} \sim$ \\
\hline $\mathrm{PI}_{\mathrm{HF}}$ & $5.29 \pm 23.55$ & $5.74 \pm 84.42$ & $-11 \pm 33.86$ \\
\hline $\mathrm{INS}_{\mathrm{HF}}$ & $-4.42 \pm 7.51$ & $-1.82 \pm 4.09$ & $-4.39 \pm 10.65$ \\
\hline
\end{tabular}

Note. Differences with $\mathrm{P}<0.05$.

*Second and third groups from the first.

$\sim$ Third group from the second.

When considering the characteristics of the transition process, it turned out that in the first group INSVLF is significantly higher than in the second. This was the only significant difference that we obtained as a result of a statistical analysis of the research results. According to the periodicity index, the groups did not differ from each other. Thus, the first group of children, which turned out to be the largest, showed a transition process with a pronounced aperiodic character at the lowest frequencies, while the energy value (EVLF) was the largest. This corresponds to the concept of a high-quality transition process - deviation and fast stabilization at a new level of functioning, that is, a stable type of physiological regulation (Fig. 1). On the contrary, the second variant of the transition process relative to the first reflects a low level of quality with unstable regulation at the frequencies of the LF band (Fig. 2). The highest transient power of the third option is concentrated in the decaying high-frequency component, and with a significantly lower EVLF in terms of the INSVLF indicator, it does not significantly differ from the first (Fig. 3).

When comparing the results of the proofreading test, significant differences were revealed in terms of attention concentration (AC). In terms of AC, the first group was significantly ahead of the second and third, while the $\mathrm{AC}$ in the second group was the smallest among all the studied groups.

\section{Conclusion}

The method of spectral analysis on the plane of complex frequencies is an informative method for assessing the parameters of transient processes of physiological regulation of the human body.

The indicators obtained by spectral analysis on the plane of complex frequencies contain important information about the structure of the transitional oscillatory process and can serve as indicators of the quality of the regulation system of the human body. 


\section{Краткие сообщения}

The revealed variants of transitional states of the heart rhythm made it possible to identify the relationship between the characteristics of the dynamics of the heart rhythm and the indicator of concentration during the proof test by schoolchildren, which is relevant in assessing the adaptation of children to school loads.

\section{References}

1. Baevskiy R.M. [Scientific and Theoretical Basis of Using Heart Rate Variability Analysis to Assess the Degree of Voltage of the Body's Regulatory Systems]. Tez. dokl. mezhdunar. simp. "Komp'yuternaya elektrokardiografiya na rubezhe stoletiy XX-XXI" [Proc. of Int. Simp. "Computer Electrocardiography at the Turn of the XX-XXI Centuries"]. Moscow, 1999, pp. 116-119. (in Russ.)

2. Baevskiy R.M., Berseneva A.P. Otsenka adaptatsionnykh vozmozhnostey organizma i risk razvitiya zabolevaniy [Assessment of the Adaptive Capabilities of the Body and the Risk of Developing Diseases]. Moscow, Medicine Publ., 1997, 233 p.

3. Dotsoev L.Ya., Usynin A.M., Vagner N.I., Tutatchikov A.T. [Functional State of Students 11-12 Years in Conditions of Intensive Training Loads According to the Analysis of Heart Rate Variability]. Human Physiology (RAN), 2003, vol. 29, no. 4, pp. 62-65 (in Russ.) DOI: 10.1023/A:1024977406829

4. Bezrukikh M.M. [School Risk Factors and Children's Health]. Manestr, 1999, no. 3, pp. 30-38. (in Russ.)

5. Veyn A.M., Ayrapetyants M.G., Haspekova N.B., Kuterman E.M., Kamenetskaya B.I. [Types of Heart Rhythm Reactions to Short-Term Loads and Their Connection with Psychophysical Personality Traits (Formalized Approach)]. Human Physiology, 1988, vol. 14, no. 26, p. 977. (in Russ.)

6. Marple Jr. S.L. Tsifrovoy spektral'nyy analiz i ego prilozheniya [Digital Spectral Analysis and Its Applications]. Moscow, World Publ., 1990, 584 p. (in Russ.)

7. Hayutin V.M., Lukoshkova E.V. [Spectral Analysis of Fluctuations in Heart Rate: Physiological Foundations and Its Complicating Phenomena]. Russian Physiological Journal I.N. Sechenova, 1999, vol. 85, no. 7, pp. 893-909. (in Russ.)

8. Svyatosh Y. [Analysis of Biological Signals in the Spectral Region]. Radio Electronics (News of Universities), 1996, vol. 39, no. 12, pp. 44-49. (in Russ.)

9. Ragozin A.N. [Informativeness of Spectral Indicators of Heart Rate Variability]. Bulletin of Arrhythmology, 2001, no. 22, pp. 38-40. (in Russ.)

10. Ragozin A.N., Kononov D.Yu., Usynin A.M., Mikhailov M.V. [A Computer Program to Assess the Functional State of High School Students]. Educational and Information Technology in Education, 2001, no. 4. Available at: https://journals.susu.ru/pit-edu/article/view/308/0. (in Russ.)

11. Ragozin A.N. [Computer Methods of Analyzing the Structure of Fluctuations in Heart Rate Variability]. Bulletin of the South Ural State University. Ser. Education, Health, Physical Culture, 2003, vol. 2, no. 5, pp. 194-195. (in Russ.)

12. Astakhov A.A., Ragozin A.N. [Compare Method Heart Variability (HRV) for Preanesthesia Control]. Proc. of 9th European Congress of Anesthesiology, Ierusalem, Israel, October 2-7, 1994.

13. Dotsoev L.Ya., Ragozin A.N., Usynin A.M., Astakhov A.A., Telezhkin V.F. [Study of Integrative Activity of the Heart and Blood Vessels Using Amplitude-Phase Frequency Characteristics]. Bulletin of Science and Education of Northwest Russia. Series "Applied Physics", 2017, vol. 3, no. 3, pp. 1-15. Available at: http://vestnik-nauki. ru/2017-t-3-No3-2017-v-3-No3/. (in Russ.)

14. Astakhov S., Nenasheva A., Astakhov A., Ragozin A. [Heart Rate Variability and Photoplethysmogram Indicators in Assessment of Adaptation Levels in Students Experiencing Examination Loads]. Gazzetta Medica Italiana Archivio per le Scienze Mediche, 2018 March; 177 (3 Suppl 1): 1-8. DOI: $10.23736 / \mathrm{S} 0393-3660.17 .03722-6$

15. Astakhov A.A., Ragozin A.N., Bubnova N.D., Govorov B.M. [Comparison of Absolute Values of the Five Parameters of Circulation, Their Variance, Spectral Analysis Data and Complex Frequencies in Healthy Young Men Alone]. Sbornik nauchnykh trudov simpoziuma "Medlennye kolebatel'nye protsessy v organizme cheloveka: teoriya, prakticheskoe primenenie v klinicheskoy meditsine i profilaktike" [Collection of Scientific Works of the Symposium "Slow Vibrational Processes in the Human Body: Theory, Practical Application in Clinical Medicine and Prevention"]. Novokuznetsk, 1999, pp. 23-33. (in Russ.) 
16. Ragozin A.N. [Analysis of the Spectral Structure of Non-Stationary Physiological Signals on the Plane of Complex Frequencies]. Digital Electronic Systems (Electronic Journal), 1999-2000, no. 3, pp. 34-44. (in Russ.)

17. Ragozin A.N. [Identification of Low-Frequency Vibration Parameters VLF and ULF Ranges and Analysis of Transitions on 5-minute Heart Rate Recordings Using Spectral Analysis on the Plane of Complex Frequencies] Sb. nauchnykh trudov simpoziuma. "Kolebatel'nye protsessy gemodinamiki. Pul'satsiya i flyuktuatsiya serdechno-sosudistoy sistemy" [Scientific Work of the Symposium. "The Vibrational Processes of Hemodynamics. Pulse and Fluctuation of the Cardiovascular System"]. Chelyabinsk, 2002, pp. 300-307. (in Russ.)

18. Ragozin A.N. [Increased Reliability of the Assessment of the State of the Autonomic Nervous System by the Dynamics of the Heart Rate]. Sb. nauchnykh trudov simpoziuma "Kolebatel'nye protsessy gemodinamiki. Pul'satsiya i flyuktuatsiya serdechno-sosudistoy sistemy" [Scientific Work of the Symposium "The Vibrational Processes of Hemodynamics. Pulse and Fluctuation of the Cardiovascular System"]. Chelyabinsk, 2002, pp. 307-313. (in Russ.)

19. Ragozin A.N., Astakhov Al.A. [Analysis on the Plane of Complex Frequencies and Classical Spectral Analysis in Assessing the Structure of Heart Rate Fluctuations]. Bulletin of the South Ural State University. Ser. Education, Health, Physical Culture, 2009, vol. 21, no. 39, pp. 75-82. (in Russ.) DOI: 10.14529/ozfk09.39.16

20. Astakhov Al.A., Nagornaya A.S., Naumova V.V. [Regulation of Adaptation of Hemodynamics to Aging]. Modern Technology in Medicine, 2011, vol. 1, pp. 55-60. (in Russ.)

21. Ragozin. A.N. [Spectral Analysis of Heart Rate Variability on the Plane of Complex Frequencies]. Ural Cardiology Journal, 2000, no. 2, pp. 16-20. (in Russ.)

22. Shchelokova O.I. [Safety in Anesthesia, Intensive Care and Resuscitation]. Bulletin of the Council of Young Scientists and Specialists of Chelyabinsk Region, 2014, no. 3 (Sept.), pp. 57-66. (in Russ.)

23. Astakhov A.A. Adaptatsionnyye protsessy gemodinamiki pri razlichnykh variantakh anestezii $i$ intensivnoy terapii u patsiyentov otdeleniy reanimatsii. Dis. doktora meditsinskikh nauk [Adaptation Processes of Hemodynamics with Various Variants of Anesthesia and Intensive Care in Patients of Intensive Care Units. Doct. sci. diss.]. Ekaterinburg, 2012, 264 p.

Received 11 November 2019

УДК $612.17(075.8)$

DOI: $10.14529 /$ ctcr200116

\title{
ИССЛЕДОВАНИЕ ПЕРЕХОДНЫХ ПРОЦЕССОВ СЕРДЕЧНОГО РИТМА НА ПЛОСКОСТИ КОМПЛЕКСНЫХ ЧАСТОТ У ДЕТЕЙ ШКОЛЬНОГО ВОЗРАСТА ПРИ ВЫПОЛНЕНИИ КОРРЕКТУРНОЙ ПРОБЫ
}

\author{
А.Н. Рагозин ${ }^{1}$, В.Ф. Тележкин ${ }^{1}$, А.М. Усынин ${ }^{2}$, Л.Я. Доцоев ${ }^{3}$, \\ А.Д. Плетенкова ${ }^{1}$, Б.Б. Саидов ${ }^{1,4}$ \\ ${ }^{1}$ Южно-Уральский государственный университет, г. Челябинск, Россия, \\ ${ }^{2}$ Южно-Уральский государственный медицинский университет, г. Челябинск, Россия, \\ ${ }^{3}$ Южно-Уральский государственный гуманитарно-педагогический университет, \\ г. Челябинск, Россия, \\ ${ }^{4}$ Таджикский технический университет имени академика М.С. Осими, \\ е. Душанбе, Республика Таджикистан
}

\begin{abstract}
Введение. Изложена методика обработки экспериментальных данных, полученных в виде изменяющегося во времени нестационарного сигнала. При экспериментальном изучении переходных процессов, связанных с изменением сердечного ритма у школьников, при прове-
\end{abstract}




\section{Краткие сообщения}

дении корректурной пробы возникла необходимость в разработке новой эффективной методики обработки результатов динамических измерений. Цель исследования. Рассмотреть основные положения указанной методики, в основе которой лежит метод Прони, и возможности ее использования в области исследований изменений вариабельности сердечного ритма (BCP) в ответ на различные функциональные пробные воздействия. Материалы и методы. Традиционные подходы, связанные с вычислением спектральной плотности мощности (СПМ) и основанные на классических спектральных методах, получили в настоящее время очень широкое распространение. Для нестационарных зависимостей ВСР модель постоянных ритмов неприменима. Для спектрального анализа временных зависимостей ВСР, отражающих переходные процессы (нестационарные процессы), предлагается применять спектральный анализ на плоскости комплексных частот (СКЧ). СКЧ является обобщением обычного спектра. В основе расчета СКЧ лежит процедура Прони, основанная на параметрическом моделировании. Результаты. СКЧ отражает частотную структуру колебаний нестационарных физиологических сигналов, поэтому может использоваться для их классификации. Показано, что применение спектрального анализа на плоскости комплексных частот для переходных процессов сердечного ритма делает возможным (по параметрам СКЧ) расчет в целях диагностики, числовых значений параметров, характеризующих реакции различных регуляторных механизмов ритма сердца в ответ на различные функциональные пробные воздействия. Заключение. Лучшие результаты, по сравнению с методами классического спектрального анализа, для анализа переходных процессов в виде сигнала ВСР дали подходы, основанные на использовании спектрального анализа на плоскости комплексных частот.

Ключевые слова: изменения сердечного ритма, метод Прони, метод спектрального анализа на плоскости комплексных частот, физиологические сигналь, сердечный ритм, параметрические модели.

\section{Лuтература}

1. Баевский, Р.М. Научно-теоретические основы использования анализа вариабельности сердечного ритма для оценки степени напряжения регуляторных систем организма / Р.М. Баевский // Тез. докл. междунар. симп. «Компьютерная электрокардиография на рубеже столетий XX-XXI». - М., 1999. - C. 116-119.

2. Баевский, Р.М. Оиенка адаптаџионных возможностей организма и риск развития заболеваний / Р.М. Баевский, А.П. Берсенева. - М.: Медииина, 1997. - 233 с.

3. Функииональное состояние учашихся 11-12 лет в условиях интенсивных учебных нагрузок по данным анализа вариабельности сердечного ритма / Л.Я. Доцоев, А.М. Усынин, Н.И. Вагнер, А.Т. Тутатчиков // Физиология человека (РАН). - 2003. - Т. 29, № 4. - С. 62-65.

4. Безруких М.М. Школьные факторы риска и здоровья детей // Манестр. - 1999. - № 3. C. $30-38$.

5. Типы реакций ритма сердияа на кратковременные нагрузки и их связь с психофизическими особенностями личности (формализованный подход) / А.М. Вейн, М.Г. Айрапетяни, Н.Б. Хаспекова и др. // Физиология человека. - 1988. - Т. 14, № 26. - С. 977.

6. Марпл-мл., С.Л. Цифровой спектральный анализ и его приложения / С.Л. Марпл-мл. - М.: Mup, 1990. - 584 c.

7. Хаютин, В.М. Спектральный анализ колебаний частоты сердиебиений: физиологические основы и осложняющие его явления / В.М. Хаютин, Е.В. Лукошкова // Российский физиологический журнал им. И.Н. Сеченова. - 1999. - Т. 85, № 7. - С. 893-909.

8. Святош, Й. Анализ биологических сигналов в спектральной области / Й. Святош // Радиоэлектроника (Изв. вузов). - 1996. - Т. 39, № 12. - С. 44-49.

9. Рагозин, А.Н. Информативность спектральных показателей вариабельности сердечного ритма / А.Н. Рагозин // Вестник аритмологии. - 2001. - № 22. - C. 38-40. - http://vestar.ru/ atts/1563/1563ragozin.pdf.

10. Компьютерная программа для оценки функционального состояния учащихся средних школ / А.Н. Рагозин, Д.Ю. Кононов, А.М. Усынин, М.В. Михайлов // Педагогические и информаиионные технологии в образовании. - 2001. - № 4. - https://journals.susu.ru/pit-edu/article/view/308/0.

11. Рагозин, А.Н. Компьютерные методы анализа структуры колебаний вариабельности 
сердечного ритма / А.Н. Рагозин // Вестник ЮУрГУ. Серия «Образование, здравоохранение, физическая культура». - 2003. - Bыın. 2, № 5. - C. 194-195.

12. Astahov, A.A. Compare method heart variability (HRV) for preanesthesia control / A.A. Astahov, A.N. Ragozin // Proc. of 9th European Congress of Anesthesiology, Ierusalem, Israel, October 2-7, 1994.

13. Исследование интегративной деятельности сердца и сосудов с помощью амплитуднофазовых частотных характеристик / Л.Я. Доцуоев, А.Н. Рагозин, А.М. Усынин и др. // Вестник науки и образования Северо-Запада России. Серия «Прикладная физика». - 2017. - T. 3, № 3. C. 1-15. - http://vestnik-nauki.ru/2017-m-3-№3-2017-v-3-№3/.

14. Heart rate variability and photoplethysmogram indicators in assessment of adaptation levels in students experiencing examination loads / S. Astakhov, A. Nenasheva, A. Astakhov, A. Ragozin // Gazzetta Medica Italiana Archivio per le Scienze Mediche, 2018 March; 177 (3 Suppl 1): 1-8. DOI: 10.23736/S0393-3660.17.03722-6

15. Сопоставление абсолютных значений пяти параметров кровообрашения, их дисперсии, данных спектрального анализа и комплексных частот у здоровых молодых мужчин в покое / А.А. Астахов, А.Н. Рагозин, Н.Д. Бубнова, Б.М. Говоров // Сборник научных трудов симпозиума «Медленные колебательные прочессы в организме человека: теория, практическое применение в клинической медицине и профилактике». - Новокузнецк, 1999. - С. 23-33.

16. Рагозин, А.Н. Анализ спектральной структуры нестационарных физиологических сигналов на плоскости комплексных частот / А.Н. Рагозин // Цифровые радиоэлектронные системы (электронный журнал). - 1999-2000. - №3. - С. 34-44.

17. Рагозин, А.Н. Идентификация параметров низкочастотных колебаний VLF и ULF диапазонов и анализ переходных прочессов по 5-минутным записям сердечного ритма с использованием спектрального анализа на плоскости комплексных частот / А.Н. Рагозин // Сборник научных трудов симпозиума «Колебательные процессы гемодинамики. Пульсация и флюктуация сердечно-сосудистой системы». - Челябинск, 2002. - С. 300-307.

18. Рагозин, А.Н. Повышение достоверности оценки состояния вегетативной нервной системы по динамике сердечного ритма / А.Н. Рагозин // Сборник научных трудов симпозиума «Колебательные процессы гемодинамики. Пульсаџия и флюктуащия сердечно-сосудистой системь». Челябинск, 2002. - С. 307-313.

19. Рагозин, А.Н. Анализ на плоскости комплексных частот и классический спектральный анализ в оченке структуры колебаний сердечного ритма / А.Н. Рагозин, Ал.А. Астахов // Вестник ЮУрГУ. Серия «Образование, здравоохранение, физическая культура». - 2009. - Bылn. 21, № 39. C. 75-82. DOI: 10.14529/ozfk09.39.16

20. Астахов, Ал.А. Регуляции адаптащчии гемодинамики к старению / Ал.А. Астахов, А.С. Нагорная, В.В. Наумова // Современные технологии в медицине. - 2011 - Bып. 1. - C. 55-60. https://cyberleninka.ru/article/n/regulyatsiya-adaptatsii-gemodinamiki-k-stareniyu.

21. Рагозин, А.Н. Спектральный анализ вариабельности сердечного ритма на плоскости комплексных частот / А.Н. Рагозин // Уральский кардиологический журнал. - 2000. - № 2. C. 16-20.

22. Щелокова, О.И. Безопасность при анестезии, интенсивной терапии и реанимащии / О.И. Щелокова // Материаль Областной научно-практической конференции молодых ученых и студентов «Экстремальные ситуащии в жизни мегаполиса». Вестник Совета молодых учёных и специалистов Челябинской области. - Челябинск, 2014. - № 3 (сентябрь). - С. 57-66.

23. Астахов, А.А. Адаптационные процессы гемодинамики при различных вариантах анестезии и интенсивной терапии у пацчиентов отделений реанимации: дис. ... д-ра мед. наук: 14.01 .20 анестезиология и реаниматология / А.А. Астахов. - Екатеринбург, 2012. - 264 с. 
Рагозин Андрей Николаевич, канд. техн. наук, доцент кафедры инфокоммуникационных технологий, Южно-Уральский государственный университет, г. Челябинск; ragozinan@susu.ru.

Тележкин Владимир Федорович, д-р техн. наук, профессор кафедры инфокоммуникационных технологий, Южно-Уральский государственный университет, г. Челябинск; telezhkinvf@ susu.ru.

Усынин Анатолий Михайлович, врач высшей категории, проблемная научно-исследовательская лаборатория медленных процессов гемодинамики кафедры анестезиологии и реанимации, Южно-Уральский государственный медицинский университет, г. Челябинск; dgb1@uzag74.ru.

Доцоев Леонид Яковлевич, канд. мед. наук, доцент, Южно-Уральский государственный гуманитарно-педагогический университет, г. Челябинск; docoev@cspu.ru.

Плетенкова Анастасия Дмитриевна, студент кафедры защиты информации, Южно-Уральский государственный университет, г. Челябинск; nastya.pletenkova@mail.ru.

Саидов Бехруз Бадридинович, аспирант кафедры инфокоммуникационных технологий, Южно-Уральский государственный университет, г. Челябинск; Таджикский технический университет имени академика М.С. Осими, г. Душанбе, Республика Таджикистан; matem.1994@mail.ru.

Поступила в редакцию 11 ноября 2019 г.

\section{ОБРАЗЕЦ ЦИТИРОВАНИЯ}

Digital Spectral Analysis on the Plane of Complex Frequencies of Transients of the Heart Rhythm at Schoolchildren at Performing a Proof Test / A.N. Ragozin, V.F. Telezhkin, A.M. Usynin et al. // Вестник ЮУрГУ. Серия «Компьютерные технологии, управление, радиоэлектроника». - 2020. - Т. 20, № 1. - С. 161-170. DOI: $10.14529 / \mathrm{ctcr} 200116$

\section{FOR CITATION}

Ragozin A.N., Telezhkin V.F., Usynin A.M., Dotsoev L.Ya., Pletenkova A.D., Saidov B.B. Digital Spectral Analysis on the Plane of Complex Frequencies of Transients of the Heart Rhythm at Schoolchildren at Performing a Proof Test. Bulletin of the South Ural State University. Ser. Computer Technologies, Automatic Control, Radio Electronics, 2020, vol. 20, no. 1, pp. 161-170. DOI: $10.14529 /$ ctcr200116 